\title{
Cloning and characterization of a tryptophanase gene from Enterobacter aerogenes SM-18
}

\author{
Kosei Kawasaki, ${ }^{1}$ Atsushi Yokota, ${ }^{1 *}$ Shigeru Oita, ${ }^{1} \uparrow$ Chisa Kobayashi, ${ }^{1} \ddagger$ \\ Shuji YoshiKawa, ${ }^{1} \S$ ShIN-ICHi KaWamoto, ${ }^{2}$ Shoichi TaKaO $^{1} \|$ and Fusao Tomita ${ }^{1}$ \\ ${ }^{1}$ Laboratory of Applied Microbiology and ${ }^{2}$ Laboratory of Molecular Biology, Faculty of Agriculture, \\ Hokkaido University, Kita-9, Nishi-9, Kita-ku, Sapporo 060, Japan
}

(Received 14 April 1993; revised 12 July 1993; accepted 21 July 1993)

\begin{abstract}
A tryptophanase gene from Enterobacter aerogenes SM-18 was cloned and sequenced. The structural gene for tryptophanase, tna $A$, consisted of 1389 bp encoding 462 amino acid residues, and its nucleotide sequence and deduced amino acid sequence showed significant homology to those of tnaA from Escherichia coli K12. A short open reading frame consisting of 31 amino acid residues was found upstream of $t n a A$, and it showed some similarity to the $E$. coli tna $C$ gene known to be a cis-acting regulatory element for transcription. A partial open reading frame homologous to the $5^{\prime}$ end of $E$. coli tnaB was observed at the $3^{\prime}$-flanking region of $t$ na $A$. These genes may thus constitute an operon as in $E$. coli.
\end{abstract}

\section{Introduction}

Tryptophanase is a catabolic enzyme that catalyses the degradation of L-tryptophan to indole, pyruvic acid and ammonia by an $\alpha, \beta$-elimination reaction, and requires pyridoxal 5'-phosphate as a co-factor (Wood et al., 1947; Snell, 1975). This enzyme has been found mainly in enteric bacteria. The genes for tryptophanase from Escherichia coli K12 (Deeley \& Yanofsky, 1981), Proteus vulgaris (Kamath \& Yanofsky, 1992), Symbiobacterium thermophilum (Hirahara et al., 1992) and Alcaligenes faecalis (Omori et al., 1987) have been cloned, and the first three have been sequenced.

\footnotetext{
* Author for correspondence. Tel. +81117263523 ; fax +8111716 0879 .

$\dagger$ Present address: National Food Research Institute, Ministry of Agriculture, Forestry and Fisheries, Tsukuba 305, Japan.

$\ddagger$ Present address: Technology and Engineering Laboratories, Ajinomoto Co. Inc., Kawasaki 210, Japan.

$\S$ Present address: Hokkaido Food Processing Research Centre, Ebetsu 069, Japan.

$\|$ Present address: Department of Food Science, Rakuno Gakuen University, Ebetsu 069, Japan.
}

Abbreviations: Sm, streptomycin; Km, kanamycin; Tc, tetracycline; Ap, ampicillin; NTG, $N$-methyl- $N^{\prime}$-nitro- $N$-nitrosoguanidine; CRPcAMP, cyclic AMP receptor protein-cyclic AMP complex.

The DDBJ/EMBL/GenBank accession no. for the sequence reported in this paper is D14297.
Since the reverse reaction of tryptophanase is possible at high concentrations of ammonia and pyruvic acid, this enzyme may be used as a catalyst for the production of L-tryptophan (Watanabe \& Snell, 1972; Nakazawa et al., $1972 a, b$ ). We have tried to improve the industrial feasibility of L-tryptophan production using tryptophanase, in which one of the substrates, pyruvic acid, is supplied economically by microbial fermentation (Takao et al., 1984; Yokota \& Takao, 1984, 1989; Yokota et al., 1989; Oita et al., 1990). A pyruvic-acid-producing mutant of Enterobacter aerogenes, strain LT-94 was constructed from a high-tryptophanase strain, Ent. aerogenes AHU1540. After pyruvic acid was produced from glucose by strain LT-94, L-tryptophan production was achieved enzymically by direct addition of the remaining substrates, i.e. indole and ammonia, to the fermentation broth (Oita et al., 1990).

The amount of L-tryptophan production depended mainly on the tryptophanase activity of the producer, and thus it seemed necessary to increase the activity of tryptophanase in order to improve L-tryptophan production (Oita et al., 1990). The induction of tryptophanase in this strain is severely repressed by glucose or pyruvic acid (Oita et al., 1990). Thus, it is important to release repression in order to get higher enzyme activity. For these purposes, we attempted to clone and characterize the tryptophanase gene (tna gene) from Ent. aerogenes SM-18 as presented in this paper. 


\section{Methods}

Media. LB medium containing $10 \mathrm{~g}$ Bacto-Tryptone (Difco) $\mathrm{l}^{-1}, 5 \mathrm{~g}$ Bacto-Yeast Extract (Difco) $\mathrm{l}^{-1}$ and $5 \mathrm{~g} \mathrm{NaCl}^{-1}$ was used as the complete medium. LB-HEPES was used for the study of tryptophanase induction, and was prepared by adding $0.1 \mathrm{M}$-HEPES and $0.5 \mathrm{~mm}-$ pyridoxin. $\mathrm{HCl}$ to $\mathrm{LB}$ followed by adjustment of the $\mathrm{pH}$ to $7 \cdot 0$. The tn $\mathrm{a}^{+}$selective medium contained M9 minimal salts (Miller, 1972), $4 \mathrm{~g}$ glycerol $\mathrm{l}^{-1}, 1 \mathrm{~g}$ Bacto-Vitamin Assay Casamino acids (Difco) $\mathrm{l}^{-1}, 10 \mathrm{mg}$ indole $\mathrm{l}^{-1}, 50 \mathrm{mg}$ 5-methyl-DL-tryptophan (5MT, Nacalai Tesque Inc., Kyoto, Japan) $\mathrm{l}^{-1}, 50 \mathrm{mg}$ each of L-threonine and L-leucine $\mathrm{l}^{-1}, 200 \mu \mathrm{g}$ thiamin. $\mathrm{HCl} \mathrm{l}^{-1}$ and $1 \mu \mathrm{M}-\mathrm{FeCl}_{3}$. The L-tryptophan analogue 5MT was added as an inducer for tryptophanase (Yudkin, 1976). These media were solidified by $20 \mathrm{~g}^{\text {Bacto-Agar }}$ (Difco) ${ }^{-1}$ when used in plates.

Bacterial strains, plasmids and phages. Bacterial strains, plasmids and phages used in this study are listed in Table 1.

Construction of E. coli strains for cloning the tha gene. Strain TR11M, which has both L-tryptophan auxotrophy and a tryptophanase defect, was used for detection of the tna gene by complementation on $\mathrm{tna}^{+}$ selective medium in cloning of the tna gene, and was constructed from E. coli $\mathrm{C} 600 \mathrm{r}^{-} \mathrm{m}^{-}$as follows. Among the tryptophan auxotrophs derived by UV mutagenesis, a mutant (strain T4) unable to utilize indole for growth was selected as a $\operatorname{trp} B$-defective strain. This strain was further mutagenized by treatment with NTG in order to obtain a tryptophanase-negative mutant. The selection of the tryptophanasenegative mutants was carried out by penicillin $\mathrm{G}$ enrichment in the $\mathrm{tna}^{+}$ selective medium, followed by replica-plating using the $t \mathrm{na}^{+}$selective agar medium supplemented with $50 \mathrm{mg}$ L-tryptophan $\mathrm{l}^{-1}$ as a master plate and one without L-tryptophan as the selective plate. Strain TR11 was obtained as a representative strain. The inability of this strain to synthesize tryptophanase protein was confirmed by SDS-PAGE of total cell proteins (data not shown). Strain TRIIR was obtained by conjugation of strain TR 11 with E. coli MCL31 (Lorence \& Rupert, 1983), and is a recombination-defective strain. TR11M was derived by lysogenization of $\mathrm{Mu}-1$ into TR11R by the method described by Boucher et al. (1977). This lysogenization stabilized the cloned tryptophanase gene on a mobile plasmid, RP4::Mucts62, by repressing heat induction.

Induction and assay of tryptophanase. To study induction of tryptophanase, $3 \mathrm{ml}$ of a mid-exponential phase culture in LB was inoculated into $50 \mathrm{ml}$ of LB-HEPES supplemented with or without $1 \mathrm{~g}$ L-tryptophan $\mathrm{I}^{-1}$, and cultured with reciprocal shaking at $37^{\circ} \mathrm{C}$ for $12 \mathrm{~h}$. For repressing conditions, LB-HEPES supplemented with both $1 \mathrm{~g} \mathrm{~L}$-tryptophan $\mathrm{l}^{-1}$ and $10 \mathrm{~g}$ glucose $\mathrm{l}^{-1}$ was used, and the culture time was shortened to $6 \mathrm{~h}$. Cells were collected by centrifugation, washed

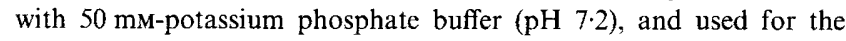
assay. Tryptophanase activity was determined by measuring indole formation from L-tryptophan by the enzyme reaction as described by DeMoss \& Moser (1969) except that the concentration of pyridoxal 5'phosphate in the complete reaction mixture was increased to $130 \mathrm{mg} \mathrm{l}^{-1}$. One unit of tryptophanase activity was defined as the amount of the enzyme that formed $1 \mu \mathrm{mol}$ indole $\mathrm{min}^{-1}$ under these assay conditions. Activity was expressed as units per mg dry wt cells.

Detection of the $\mathrm{Tna}^{+}$phenotype. The $\mathrm{Tna}^{+}$phenotype of the transconjugants or transformants was checked by detecting indole liberated from L-tryptophan into the culture medium by the tryptophanase reaction. Cells were grown in LB and the culture broth supernatant was mixed with an equal volume of colour reagent (DeMoss \& Moser, 1969).

DNA manipulations. Recombinant techniques were according to standard methods (Sambrook et al., 1989). Extraction of the large-size plasmids pRMT33 and pRMT38 was done by the method of Shibano et al. (1985). Transformation of $E$. coli strains was carried out by the method of Hanahan (1985).

Cloning of the tha gene from Ent. aerogenes SM-18. Cloning of the tna gene was carried out basically by the method of Deeley \& Yanofsky (1981) using a mobile plasmid, RP4:: Mucts62 (Murooka et al., 1981). Ent. aerogenes SM-18RM was used as a donor strain, and a tryptophanase-defective strain, $E$. coli $\mathrm{TR} 11 \mathrm{M}$ was used as recipient strain. Strain SM-18RM was constructed by conjugation of Ent. aerogenes SM-18 with $E$. coli $\mathrm{K}-12 \mathrm{MuR}$ (pGMI117) by the method of Murooka et al. (1981). The conjugants were selected on LB agar plates containing $150 \mu \mathrm{g} \mathrm{Ap} \mathrm{m}^{-1}$ and $100 \mu \mathrm{g} \mathrm{Sm}$ sulphate $\mathrm{ml}^{-1}$. The doner, Ent. aerogenes SM-18RM was cultured in LB at $39^{\circ} \mathrm{C}$ without shaking for $16 \mathrm{~h}$ to allow partial heat induction of temperature-sensitive $\mathrm{Mu} c \mathrm{cts}$. The culture broth was mixed with a mid-exponential phase culture of $E$. coli TR11M in LB, and the subsequent protocols for conjugative transfer of RP4::Mucts62 from Ent. aerogenes to E. coli were by the method of Murooka et al. (1981) with the following modifications: the conjugated cells on filter membrane were resuspended in saline, and washed with saline three times to remove L-tryptophan, and appropriate dilutions were plated onto the $t n a^{+}$selective medium supplemented with $150 \mu \mathrm{g} \mathrm{Ap} \mathrm{ml}^{-1}$, and $25 \mu \mathrm{g} \mathrm{Tc} \mathrm{ml}^{-1}$. After incubation at $37^{\circ} \mathrm{C}$, two isolates were obtained as the transconjugants harbouring RP4::Mucts62::tna $a^{+}$. The plasmids were extracted, and their abilities to retransform $E$. coli $\mathrm{TR} 11 \mathrm{M}$ to $\mathrm{Tna}^{+}$were confirmed. They were designated pRMT33 and pRMT38, respectively. Plasmid pRMT33 was digested with HindIII, and the fragments generated were ligated into the HindIII site of pBR328. The ligation mixture was used to transform $E$. coli $\mathrm{TR} 11 \mathrm{R}$ selecting for $\mathrm{Tna}^{+}$. A plasmid containing a $30 \mathrm{kbp}$ HindIII fragment was designated pBT1. This plasmid was digested with PstI and DNA fragments were ligated into the PstI site of pUC19 and the ligation mixture was used to transform TR11R to $\mathrm{Tna}^{+}$. A clone that showed $\mathrm{Tna}^{+}$was selected, and its plasmid, which contained a $5.8 \mathrm{kbp}$ Pst I fragment, was designated pKT403.

DNA sequencing. The target DNA fragments were subcloned into pUC118 and/or pUC119. A series of nested deletions of each plasmid was constructed by the method of Yanisch-Perron et al. (1985) with mung-bean nuclease. Single-stranded plasmid DNA for the sequencing template was prepared by infecting E. coli MV1184 harbouring the plasmid with M13KO7. Dideoxy sequencing was performed using the Sequenase version 2.0 DNA sequencing kit (United States Biochemical Corp.) and $\left[\alpha-{ }^{32} \mathrm{P}\right] \mathrm{dCTP}$ (Amersham). Computer analyses of nucleotide sequence and resulting amino acid sequence were performed with the software package DNASIS (Hitachi Software Engineering Co., Japan).

$S D S-P A G E$. This was done by the method of Laemmli (1970) with an $8 \%(\mathrm{w} / \mathrm{v})$ acrylamide separation gel. Gels were stained with Coomassie Brilliant Blue R-250. Densitometric analysis was done with a Shimadzu model CS-9000.

\section{Results and Discussion}

\section{Subcloning and localization of the tha gene}

A partial restriction map of pKT403 was determined (Fig. 1). Southern blot analysis revealed that the cloned fragment originated from the Ent. aerogenes chromosome (data not shown). To locate the tna gene, deletion derivatives (from pKT404 to pKT408, and pKT421) were constructed from pKT403 as described in Table 1, and their abilities to complement $\mathrm{Tna}^{-}$were examined in E. coli TR11R with L-tryptophan as the inducer. As 
Table 1. Bacterial strains, phages and plasmids

\begin{tabular}{|c|c|c|}
\hline & Genotype, phenotype or description & $\begin{array}{l}\text { Source or } \\
\text { reference }\end{array}$ \\
\hline \multicolumn{3}{|l|}{ Enterobacter aerogenes } \\
\hline SM-18 & $\mathrm{Sm}^{\mathrm{r}}$ derived from AHU1540 & $\begin{array}{l}\text { Yokota \& Takao } \\
\text { (1984) }\end{array}$ \\
\hline SM-18RM & $\begin{array}{l}\mathrm{RP} 4:: \mathrm{Mucts} 62 \mathrm{Km}^{\mathrm{r}} \mathrm{Tc}^{\mathrm{s}} \mathrm{Ap}^{\mathrm{r}} \text {, conjugation of } \\
\mathrm{SM}-18 \times \text { E. coli } \mathrm{K} 12 \mathrm{MuR}(\mathrm{pGMI} 117)\end{array}$ & This study \\
\hline \multicolumn{3}{|l|}{ Escherichia coli } \\
\hline K12MuR(pGMI117) & RP4::Mucts62 $\mathrm{Km}^{\mathrm{r}} \mathrm{Tc}^{\mathrm{s}} \mathrm{Ap}^{\mathrm{r}}$ & J. Fourment \\
\hline $\mathrm{C} 600 r^{-} m^{-}$ & thr-1 leuB6 thi-1 hsdSI lacYI tonA21 $\lambda^{-}$supE44 & ATCC 33525 \\
\hline MCL31 & $\begin{array}{l}\text { HfrPO201 } \Delta(\text { gpt-lac }) 5 \text { relal rpsE2123 thi-1 } \\
\text { supE44 TP3 } \Delta(\operatorname{srl}-\text { recA }) 306:: \mathrm{Tn} 10\left(\mathrm{Tc}^{5}\right)\end{array}$ & $\begin{array}{l}\text { Lorence \& Rupert } \\
\text { (1983) }\end{array}$ \\
\hline MV1184 & $\begin{array}{l}\text { ara } \Delta(\text { lac-proAB }) \text { rpsL thi }(\phi 80 \text { lac } Z \Delta \mathrm{M} 15) \\
\Delta(\operatorname{srl}-\operatorname{rec} A) 306:: \operatorname{Tn} 10\left(\mathrm{Tc}^{\mathrm{r}}\right) \mathrm{F}^{\prime}[\operatorname{traD} 36 \text { proAB } \\
\left.\text { lacI }{ }^{\mathrm{q}} \text { lac } Z \Delta \mathrm{M} 15\right]\end{array}$ & $\begin{array}{l}\text { Vieira \& Messing } \\
\text { (1987) }\end{array}$ \\
\hline $\mathrm{T} 4$ & $\begin{array}{l}\text { Trp }{ }^{-} \text {derivative from } \mathrm{C} 600 \mathrm{r}^{-} \mathrm{m}^{-} \text {induced by } \mathrm{UV} \\
\text { treatment, probably } \operatorname{trp} B \text { defective }\end{array}$ & This study \\
\hline TR11 & $\begin{array}{l}\text { Tna }^{-} \text {derivative from } \mathrm{T} 4 \text { induced by NTG } \\
\text { treatment }\end{array}$ & This study \\
\hline TR11R & $\begin{array}{l}\text { TR11 } 1(\operatorname{srl}-r e c A) 306:: \operatorname{Tn} 10\left(\mathrm{Tc}^{\mathrm{r}}\right) \text {, conjugation } \\
\text { of TR11 } \times \text { MCL } 31\end{array}$ & This study \\
\hline TR11M & TR11R Mu-1 lysogen & This study \\
\hline \multicolumn{3}{|l|}{ Phages } \\
\hline $\mathrm{Mu}-1$ & $\mathrm{Mu} c^{+}$ & ATCC 23724-B9 \\
\hline $\mathrm{M} 13 \mathrm{KO} 7$ & $\mathrm{Km}^{\mathrm{r}}$ & $\begin{array}{l}\text { Vieira \& Messing } \\
\text { (1987) }\end{array}$ \\
\hline \multicolumn{3}{|l|}{ Plasmids } \\
\hline pBR328 & Cloning vector, $\mathrm{Ap}^{\mathrm{r}} \mathrm{Tc}^{\mathrm{r}} \mathrm{Cm}^{\mathrm{r}}$ & $\begin{array}{l}\text { Soberon et al. } \\
(1980)\end{array}$ \\
\hline pUC18 and pUC19 & Cloning vector, $\mathrm{Ap}^{\mathrm{r}}$ & $\begin{array}{l}\text { Yanisch-Perron } \\
\text { et al. (1985) }\end{array}$ \\
\hline pUC118 and pUC119 & Cloning vector, $\mathrm{Ap}^{\mathrm{r}}$ & $\begin{array}{l}\text { Vieira \& Messing } \\
\text { (1987) }\end{array}$ \\
\hline pRMT33 and pRMT38 & $\begin{array}{l}\text { RP4:: Mu cts } 62 \text { inserted with } t n a^{+} \text {fragment from } \\
\text { Ent. aerogenes } \mathrm{SM}-18\end{array}$ & This study \\
\hline pBT1 & $\begin{array}{l}30 \mathrm{kbp} \text { (approximate) HindIII fragment from } \\
\text { pRMT33 cloned in pBR328 }\end{array}$ & This study \\
\hline pKT403 & $\begin{array}{l}5.8 \mathrm{kbp} \text { Pst I fragment from pBT1 cloned in } \\
\text { pUC19 at the same restriction site }\end{array}$ & This study \\
\hline pKT404 & pKT403 cut with $K p n I$ and recircularized & This study \\
\hline pKT405 & $\begin{array}{l}\text { pKT } 403 \text { cut with } A c c I^{*} \text { and } H i n c I I, \text { and } \\
\text { recircularized }\end{array}$ & This study \\
\hline pKT406 & $\begin{array}{l}5 \cdot 2 \mathrm{kbp} \text { DraI-EcoRI fragment from pKT403 } \\
\text { cloned in pUC19 cut with SmaI-EcoRI }\end{array}$ & This study \\
\hline pKT407 & pKT403 cut with $S p h$ I and recircularized & This study \\
\hline pKT408 & $\begin{array}{l}3.5 \mathrm{kbp} S a c \mathrm{I}-E c o \mathrm{RI} \text { fragment from pKT } 403 \\
\text { cloned in pUC19 cut with the same enzymes }\end{array}$ & This study \\
\hline pKT421 & $\begin{array}{l}2.8 \mathrm{kbp} S p h \mathrm{I}-K p n \mathrm{I} \text { fragment from pKT } 403 \\
\text { cloned in pUC19 cut with the same enzymes }\end{array}$ & This study \\
\hline pKT321 & $\begin{array}{l}2.8 \mathrm{kbp} S p h \mathrm{I}-K p n \mathrm{I} \text { fragment from pKT } 403 \\
\text { cloned in pUC1 } 8 \text { cut with the same enzymes }\end{array}$ & This study \\
\hline
\end{tabular}

* This $A c c$ I terminus was blunted with bacteriophage T4 DNA polymerase before ligation.

shown in Fig. 1, the complementing activity was retained in the $2.8 \mathrm{kbp} S p h \mathrm{I}-K p n \mathrm{I}$ fragment. The expression and regulation of the tna gene coded in this $S p h \mathbf{I}-K p n \mathbf{I}$ segment were investigated (Table 2). In E. coli TR11R(pKT421), tryptophanase expression is inducible by L-tryptophan and is repressed severely by addition of glucose. Similar results were obtained with Ent. aerogenes SM-18 and E. coli TR11R(pKT403). This SphI-KpnI fragment was subcloned into pUC18 at the same restriction sites. The resulting plasmid, pKT321, which has the same fragment as pKT421, but with inverted orientation against the lac promoter of the plasmid vector, also displayed characteristics similar to pKT421. These results suggested that this segment contains promoter and other regulatory elements as well as the structural gene for tryptophanase. 


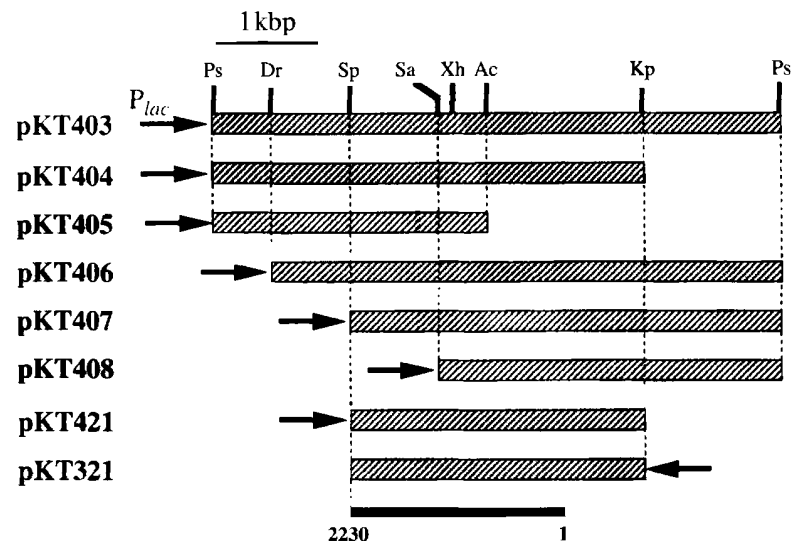

Table 2. Tryptophanase induction and its repression by glucose in Ent. aerogenes SM-18 and E. coli TRIIR transformants

The strains were cultured in LB-HEPES, either unsupplemented (not induced), or supplemented with L-tryptophan (induced) or Ltryptophan plus glucose (repressed). Details are given in Methods.

\begin{tabular}{lrrr}
\hline \hline & \multicolumn{3}{c}{$\begin{array}{c}\text { Trytophanase activity } \\
\text { [units (mg dry wt cells) }\end{array}$} \\
\cline { 2 - 3 } Strain(plasmid) & $\begin{array}{c}\text { Not } \\
\text { induced }\end{array}$ & Induced & Repressed \\
\cline { 1 - 2 } Ent. aerogenes SM-18 & 0.11 & 0.57 & $<0.01$ \\
E. coli TR11R(pUC19) & $<0.01$ & $<0.01$ & $<0.01$ \\
E. coli TR11R(pKT403) & 0.11 & 1.23 & $<0.01$ \\
E. coli TR11R(pKT421) & 0.25 & 1.27 & $<0.01$ \\
E. coli TR11R(pKT321) & 0.49 & 1.06 & $<0.01$ \\
\hline \hline
\end{tabular}

\section{SDS-PAGE analysis of total cell proteins}

This revealed that an extra protein was produced in $E$. coli TR11R(pKT421) grown under inducing conditions, which was not detected in E. coli TR11R(pUC19) (Fig. 2 ). The molecular mass of this protein was estimated to about $50 \mathrm{kDa}$. This $50 \mathrm{kDa}$ protein was also observed in Ent. aerogenes SM-18 grown under inducing conditions. A densitometric analysis of the gel revealed that the ratio of $50 \mathrm{kDa}$ protein to total cell protein was $26 \%$ for induced E. coli TR11R(pKT421) and $15 \%$ for induced Ent. aerogenes SM-18. This agreed with the results of experiments (Table 2) showing that the activity of tryptophanase in induced E. coli TR11R(pKT421) was twofold higher than that of induced Ent. aerogenes SM-18. Therefore, this $50 \mathrm{kDa}$ protein was considered to be the tryptophanase protein.

\section{Nucleotide sequence of the tha gene and deduced amino acid sequence}

The nucleotide sequence of the tna gene region in the SphI-KpnI fragment was determined from both strands. Fig. 3 shows the 2230 bp sequence including the $S p h I$ site
Complementation

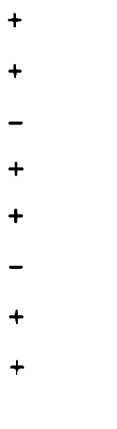

Fig. 1. Restriction map of pKT403 and complementation of $\mathrm{Tna}^{-}$by pKT403 and its deletion derivatives. Cloned DNA of each plasmid is represented by a hatched box. Arrows indicate the position and orientation of the lac promoter $\left(\mathrm{P}_{l a c}\right)$. Each plasmid was introduced into tryptophanase-defective $E$. coli TR $11 \mathrm{R}$, and its $\mathrm{Tna}^{+}$was tested. The region sequenced and shown in Fig. 3 is indicated with coordinates. +, Complementation; - , no complementation. Abbreviations for restriction sites; Ps, PstI; Dr, DraI; Sp, SphI; Sa, SacI; Xh, XhoI; Ac, AccI; $\mathrm{Kp}, K p n \mathrm{I}$.

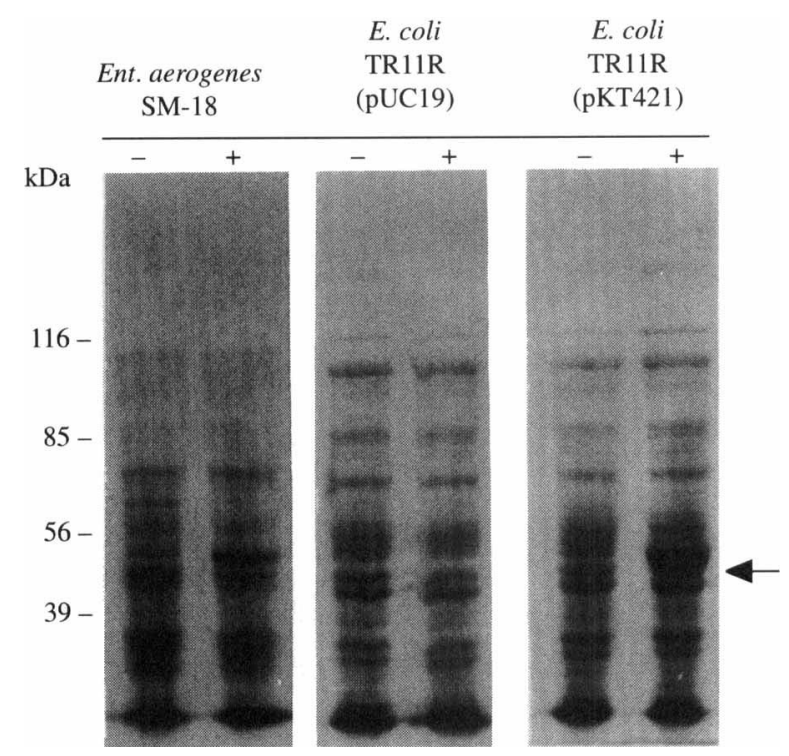

Fig. 2. SDS-PAGE analysis of proteins from whole cells. The tryptophanase was induced in Ent. aerogenes SM-18 and E. coli TR11R transformants by L-tryptophan as described in Methods. The position of the tryptophanase protein is indicated by an arrow. +, Inducing conditions;,- non-inducing conditions.

at the 3 -terminus. Computer analysis of the sequence revealed one major open reading frame (ORF) comprising $1389 \mathrm{bp}$ coding for 462 amino acids, and significant homology between the nucleotide sequences of this ORF and tnaA from E. coli K12 (Deeley \& Yanofsky, 1981). Thus, it seems to be the structural gene for tryptophanase, and was designated tnaA. A Shine Dalgarno (SD) sequence was found just before the ATG translation initiation codon. The molecular mass of the TnaA protein calculated from the predicted amino acid sequence is $51.8 \mathrm{kDa}$, which is in good agreement with the result of the SDS-PAGE (Fig. 2). The deduced amino acid sequence is $60 \%$ identical to that of $E$. coli TnaA (Fig. 4). A larger value, $70 \%$, was observed between Ent. aerogenes TnaA and $P$. vulgaris TnaA (Kamath \& Yanofsky, 1992). The lysine residue of $E$. coli TnaA (Lys-270 indicated by a triangle in Fig. 4) is known to 

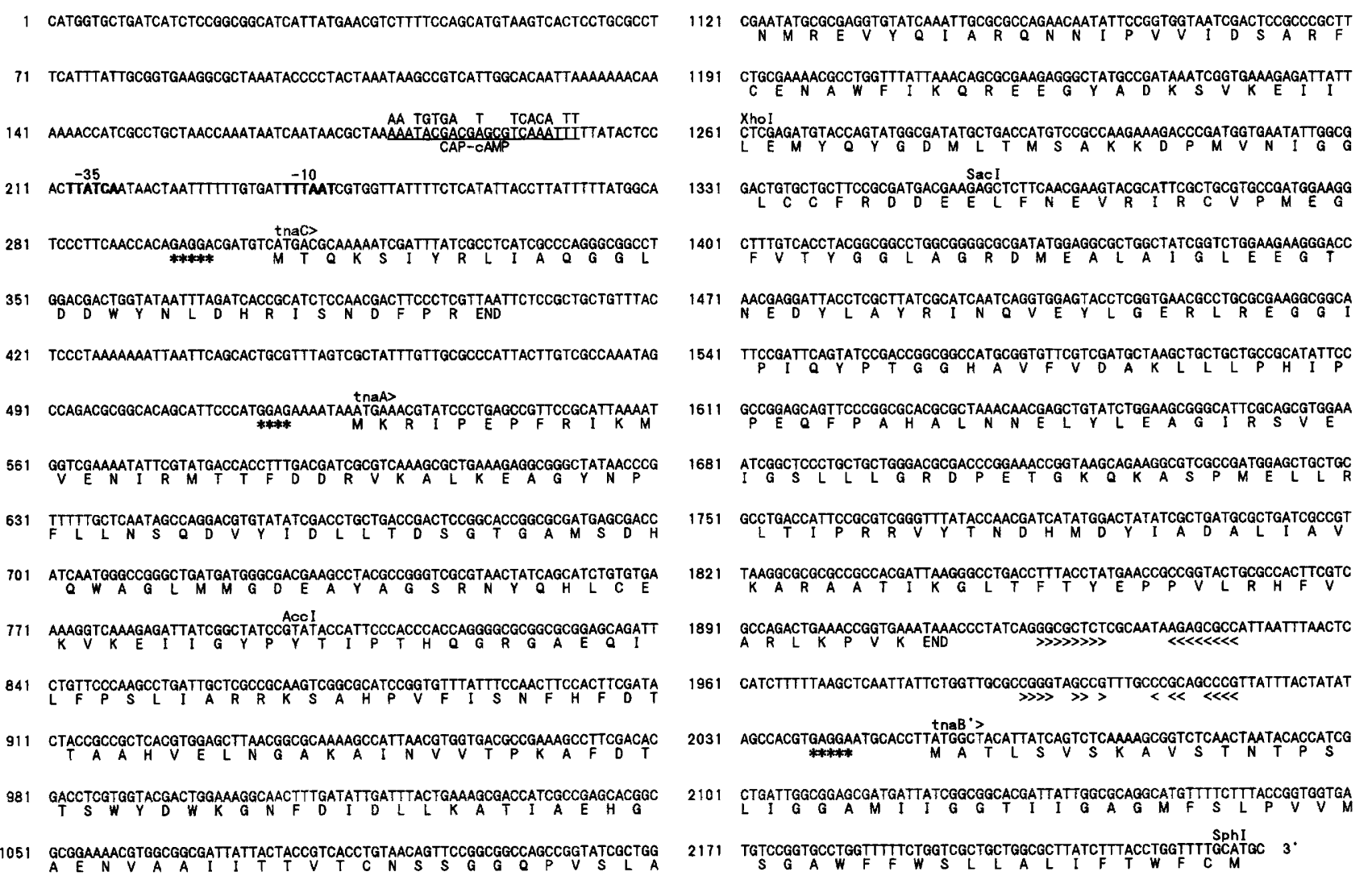

Fig. 3. Nucleotide sequence of the tnaA region. The deduced amino acid sequence is shown. A potential binding site for CRP-cAMP is shown (underlined) with its consensus sequence. Putative -35 and -10 sequences are indicated by use of bold type. Asterisks indicate the SD sequences. The inverted repeat sequences at the $3^{\prime}$-flanking region of the tna $A$ are indicated by arrowheads.

\begin{abstract}
E. AERO. (1) M---KRIPEPFRIKMVENI RMTTFDDRVKALKEAGYNPFLLNSODVYIDLLTDSGTGAMS E. COLI ( 1) MENFKHLPEPFRIRVIEPVYKRTTRAYREEAII

E. AERO. (58) DHOWAGLMMGDEAYAGSRNYQHLCEKVKEI I GYPYTIPTHOGRGAEQILFPSL IARR--E.COL1 (61) QSMAÄMMRGDEAYSGSRSYYALAESVKNIFGYOY IPTHQGRGAEQIYIPVLIKKREOE

E. AERO. (115) KSA-HP--VFISNFHFDTTAAHVELNGAKAINVVTPKAFDTTSWYOWKGNFDIDLLKATI

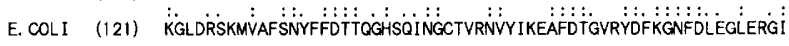

E. AERO. (172) AEHGAENVAAI ITTVTCNSSGGOPVSLANMREVYGIARQNNIPVYIDSARFCENAWF IKO

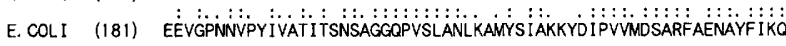

E. AERO. (232) REEGYADKSYKEI ILEMYOYGDMLTMSAKKDPMUNI GGLCCFRDDE--ELFNEVRIRCYP E. COLI (241) REAEYKDWTIEOITRETYKYADMLAMSAKKDAMPMGGLLCMKDDSFFDYYTECRTLCWV

E. AERO. (290) MEGFVTYGGLAGRDMEALAIGLEEGTNEDYLAYRINQVEYLGERLREGGIPIOYPTGGHA

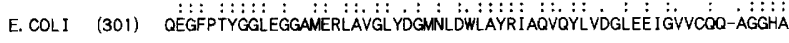

E. AERO. (350) VFVDAKLLLPHIPPEOFPAHALNNELYLEAGIRSVEIGSLLLGRDPETGKOKASPMELLR E. COLI (360) AFYDAGKLLPHIPADQFPATGLACELYYVVAGIRAVIGSLLGRDPKTGKOLPCPAELLR

E. AERO. (410) LTIPRRVYTNOHMOYIADAL IAVKARAAT IKGL TFTYEPPVLRHFVARLKPVX

E. COLI (420) LTIPRATYTOTHMOFI IEAFKHVKENAANKGLTFTYPRKLRHFTAKLKEV
\end{abstract}

Fig. 4. Alignment of the deduced amino acid sequence of Ent. aerogenes SM-18 TnaA (E.AERO.) with E. coli K12 TnaA (E.COLI). Colons indicate identical residues. Closely related residues are indicated by dots. Gaps (dashes) were introduced into the sequences to improve the alignment. A triangle $(\boldsymbol{\Delta})$ under the $E$. coli TnaA sequence indicates the lysine residue that forms a Schiff's base with pyridoxal 5'phosphate. form a Schiff's base with pyridoxal 5'-phosphate (Kagamiyama et al., 1970). In the Ent. aerogenes sequence, a lysine residue corresponding to this Lys- 270 was found.

In E. coli, tnaA is part of the tryptophanase operon. The promoter requires a CRP-cAMP for the initiation of transcription, and there is a CRP-cAMP binding site just upstream of the promoter sequence (Deeley \& Yanofsky, 1982). It has been shown that for inducible expression of the operon, translation of the short ORF coding for 24 amino acids, tnaC, located between tnaA and the promoter region, is necessary (Stewart \& Yanofsky, 1986). An antitermination site for the rho-dependent terminator, lying between tnaC and thaA, plays an important role in gene expression (Stewart \& Yanofsky, 1985; Stewart et al., 1986). Furthermore, translation of a single Trp codon in tnaC is essential for inducible expression of this operon (Gollnick \& Yanofsky, 1990). A structural gene for a tryptophan specific permease, tnaB is at the $3^{\prime}$-flanking region of tnaA (Sarsero et al., 1991). A similar gene organization has been reported in P. vulgaris (Kamath \& Yanofsky, 1992).

The nucleotide sequences surrounding Ent. aerogenes 


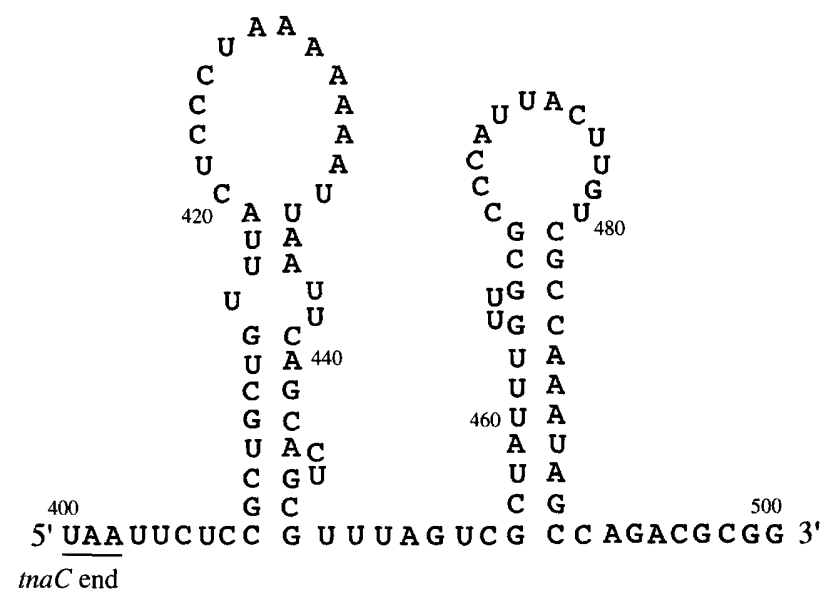

Fig. 5. Potential RNA secondary structure derived from the sequence located between thaC and tnaA.

tnaA showed a similar organization. A symmetrical sequence homologous to the consensus sequence for the CRP-cAMP binding site of E. coli (De Crombrugghe et al., 1984) was observed at about $335 \mathrm{bp}$ upstream of the tnaA transcription initiation codon. Downstream of this region, a putative promoter $(-35$ and -10$)$ was found. A small ORF coding for 31 amino acid residues preceded by a typical SD sequence was found to start $219 \mathrm{bp}$ upstream of the tnaA translation initiation codon. Comparison of this ORF with thaC of $E$. coli yielded no significant homology between them. However, there exists a single $\operatorname{Trp}$ codon as in $E$. coli tnaC, and the amino acid sequence following this Trp codon was Tyr-Asn-Leu-Glu, which is similar to that of $E$. coli (Phe-Asn-Ile-Glu; Gollnick \& Yanofsky, 1990) (Fig. 3). When we consider the importance of the Trp codon in tnaC of $E$. coli, this similarity leads us to consider this $\mathrm{ORF}$ as an equivalent of $E$. coli tnaC. Therefore, we designated this ORF tnaC. However, the function of this ORF remains to be elucidated. In $E$. coli, a rhodependent termination site was found between tha $C$ and tnaA. In Ent. aerogenes, a sequence which can form a sufficiently stable secondary structure was found between tnaC and thaA (Fig. 5). Downstream of tnaA, a partial ORF that has homology to the $5^{\prime}$ end of $E$. coli tna $B$ was found (Sarsero et al., 1991). As this partial ORF seemed to be a part of the structural gene for tryptophan permease, we designated it $t n a B^{\prime}$ (Fig. 3). Between $t n a B$ and tna $B^{\prime}$ were found two inverted repeats with stretches of $\mathrm{T}$ bases, which may serve as a rho-independent termination site (Fig. 3).

In conclusion, we have found that the organization of the tna gene from Ent. aerogenes SM-18 is similar to those from E. coli $\mathrm{K} 12$ and $P$. vulgaris. Therefore, we propose that the tna gene may constitute an operon structure in Ent. aerogenes SM-18.
We thank Dr J. Fourment for providing E. coli K12MuR(pGMI117), and Dr C.S. Rupert for providing E. coli MCL31. This work was supported in part by the Grants-in-Aid for Scientific Research (Nos 02760061 and 03760062 ) from the Ministry of Education, Science and Culture of Japan. This work was also supported in part by the Special Grant-in-Aid for Promotion of Education and Science in Hokkaido University provided by the same ministry.

\section{References}

Boucher, C., Bergeron, B., De Bertarmio, M. B. \& Dénarié, J. (1977). Introduction of bacteriophage $\mathrm{Mu}$ into Pseudomonas solanacearum and Rhizobium meliloti using the R factor RP4. Journal of General Microbiology 98, 253-263.

De Crombrugghe, B., Busby, S. \& Buc, H. (1984). Cyclic AMP receptor protein: role in transcription activation. Science $\mathbf{2 2 4}$, 831-838.

Deeley, M. C. \& Yanofsky, C. (1981). Nucleotide sequence of the structural gene for tryptophanase of Escherichia coli K-12. Journal of Bacteriology 147, 787-796.

DeEley, M. C. \& YANOFsKY, C. (1982). Transcription initiation at the tryptophanase promoter of Escherichia coli K-12. Journal of Bacteriology 151, 942-951.

DeMoss, R. D. \& MOSER, K. (1969). Tryptophanase in diverse bacterial species. Journal of Bacteriology 98, 167-171.

GollNick, P. \& YANOFSKY, C. (1990). tRNA ${ }^{\text {Trp }}$ translation of leader peptide codon 12 and other factors that regulate expression of the tryptophanase operon. Journal of Bacteriology 172, 3100-3107.

HaNAHAN, D. (1985). Techniques for transformation of E. coli. In DNA Cloning: a Practical Approach, vol. 1, pp. 109-135. Edited by D. M. Glover. Oxford: IRL Press.

Hirahara, T., Suzuki, S., Horinouchi, S. \& Beppu, T. (1992) Cloning, nucleotide sequences, and overexpression in Escherichia coli of tandem copies of a tryptophanase gene in an obligately symbiotic thermophile, Symbiobacterium thermophilum. Applied and Environmental Microbiology 58, 2633-2642.

Kagamiyama, H., Morino, Y. \& SNell, E. E. (1970). The chemical structure of tryptophanase from Escherichia coli. I. Isolation and structure of a pyridoxyl decapeptide from borohydride-reduced holotryptophanase. Journal of Biological Chemistry 245, 2819-2824.

Kamath, A. V., Yanofsky, C. (1992). Characterization of the tryptophanase operon of Proteus vulgaris. Cloning, nucleotide sequence, amino acid homology, and in vitro synthesis of the leader peptide and regulatory analysis. Journal of Biological Chemistry 267 19978-19985.

LAEMMLI, U. K. (1970). Cleavage of structural proteins during the assembly of the head of bacteriophage T4. Nature, London 227, 680-685.

LORENCE, M. C. \& RUPERT, C. S. (1983). Convenient construction of recA deletion derivatives of Escherichia coli. Journal of Bacteriology 156, 458-459.

MilLER, J. H. (1972). Experiments in Molecular Genetics, pp. 431-432. Cold Spring Harbor, NY: Cold Spring Harbor Laboratory.

Murooka, Y., Takizawa, N. \& Harada, T. (1981). Introduction of bacteriophage $\mathrm{Mu}$ into bacteria of various genera and intergeneric gene transfer by RP4:: Mu. Journal of Bacteriology 145, 358-368.

Nakazawa, H., Enei, H., OKumura, S., Yoshida, H. \& Yamada, H. (1972a). Enzymatic preparation of L-tryptophan and 5-hydroxyl-Ltryptophan. FEBS Letters $25,43-45$.

Nakazawa, H., Enei, H., Okumura, S. \& Yamada, H. (1972b). Synthesis of L-tryptophan from pyruvate, ammonia and indole. Agricultural and Biological Chemistry 36, 2523-2528.

Oita, S., Yokota, A. \& TAKaO, S. (1990). Enzymatic production of tryptophan using a lipoic acid and thiamine double auxotroph of Enterobacter aerogenes having both pyruvic acid productivity and high tryptophanase activity. Journal of Fermentation and Bioengineering 69, 256-258.

OmoRi, K., Shibatani, T. \& Tosa, T. (1987). Cloning of tryptophanase gene of Alcaligenes faecalis for effective production of L-tryptophan. Journal of Biotechnology 5, 17-28. 
Sambrook, J., Fritsch, E. F. \& Maniatis, T. (1989). Molecular Cloning: a Laboratory Manual, 2nd edn. Cold Spring Harbor, NY: Cold Spring Harbor Laboratory.

Sarsero, J. P., Wookey, P. J., Gollnick, P., Yanofsky, C. \& Pittard, A. J. (1991). A new family of integral membrane proteins involved in transport of aromatic amino acids in Escherichia coli. Journal of Bacteriology 173, 3231-3234.

Shibano, Y., Yamagata, A., Nakamura, N., IzZuka, T., Sugisaki, H. \& TAKANAMI, M. (1985). Nucleotide sequence coding for the insecticidal fragment of the Bacillus thuringiensis crystal protein. Gene 34, 243-251.

SNELL, E. E. (1975). Tryptophanase: structure, catalytic activities, and mechanism of action. Advances in Enzymology 42, 287-333.

Soberon, X., Covarrubias, L. \& Bolivar, F. (1980). Construction and characterization of new cloning vehicles. IV. Deletion derivatives of pBR322 and pBR325. Gene 9, 287-305.

STEWART, V. \& YANOFSKY, C. (1985). Evidence for transcription antitermination control of tryptophanase operon expression in Escherichia coli $\mathrm{K}-12$. Journal of Bacteriology 164, 731-740.

SteWART, V. \& YANOFSKY, C. (1986). Role of leader peptide synthesis in tryptophanase operon expression in Escherichia coli K-12. Journal of Bacteriology 167, 383-386.

Stewart, V., LANDick, R. \& YANOFSKy, C. (1986). Rho-dependent transcription termination in the tryptophanase operon leader region of Escherichia coli K-12. Journal of Bacteriology 166, 217-223.

TaKaO, S., Yokota, A.\& TANida, M. (1984). Enzymatic production of tryptophan coupled to pyruvic acid fermentation. Journal of Fermentation Technology 62, 329-334.
Vieira, J. \& Messing, J. (1987). Production of single-stranded plasmid DNA. Methods in Enzymology 153, 3-11.

Watanabe, T. \& SNell, E. E. (1972). Reversibility of the tryptophanase reaction: Synthesis of tryptophan from indole, pyruvate, and ammonia. Proceedings of the National Academy of Science of the United States of America 69, 1086-1090.

WoOD, W. A., Gunsalus, I. C. \& Umbreit, W. W. (1947). Function of pyridoxal phosphate: resolution and purification of the tryptophanase enzyme of Escherichia coli. Journal of Biological Chemistry 170, 313-321.

Yanisch-Perron, C., Vieira, J. \& Messing, J. (1985). Improved M13 phage cloning vectors and host strains: nucleotide sequences of the M13mp18 and pUC19 vectors. Gene 33, 103-119.

Yokota, A. \& TAKaO, S. (1984). Conversion of pyruvic acid fermentation to tryptophan production by the combination of pyruvic acid-producing microorganisms and Enterobacter aerogenes having high tryptophanase activity. Agricultural and Biological Chemistry 48, 2663-2668.

YокотA, A. \& TAKaO, S. (1989). Pyruvic acid production by lipoic acid auxotrophs of Enterobacter aerogenes. Agricultural and Biological Chemistry 53, 705-711.

Yokota, A., OITA, S. \& Takao, S. (1989). Tryptophan production by a lipoic acid auxotroph of Enterobacter aerogenes having both pyruvic acid productivity and high tryptophanase activity. Agricultural and Biological Chemistry 53, 2037-2044.

YudKIN, M. D. (1976). Mutations in Escherichia coli that relieve catabolite repression of tryptophanase synthesis. Mutations distant from the tryptophanase gene. Journal of General Microbiology 92 125-132. 